\title{
Two new species of Polydesmus Latreille, I802//803 from northern Spain with reinstatements of two species, and a key to the lberian Polydesmus species (Diplopoda, Polydesmida, Polydesmidae)
}

\author{
Per Djursvoll' \\ I Department of Natural History, University Museum of Bergen, Allégaten 41, 5007 Bergen, Norway \\ Corresponding author: Per Djursvoll (per.djursvoll@uib.no)
}

Academic editor: D. Vanden Spiegel | Received 1 July 2019 | Accepted 26 September 2019 | Published 11 November 2019

http://zoobank.org/C420CD3B-9C79-45D1-97CC-FA8C59D5D9EB

Citation: Djursvoll P (2019) Two new species of Polydesmus Latreille, 1802/1803 from northern Spain with reinstatements of two species, and a key to the Iberian Polydesmus species (Diplopoda, Polydesmida, Polydesmidae). ZooKeys 888: 51-65. https://doi.org/10.3897/zookeys.888.37816

\begin{abstract}
Polydesmus biscayensis sp. nov. and $P$. asturiensis sp. nov. are described and figured based on material housed in the Museo Nacional de Ciencias Naturales in Madrid. The specimens were collected in six localities in the Asturias and Cantabria provinces, including four caves. In addition, Polydesmus haroi Mauriès \& Vicente, 1977 and Polydesmus racovitzai Brolemann, 1910 are transferred from Propolydesmus Verhoeff, 1895 to Polydesmus Latreille, 1802/1803 after examining the gonopod morphology. A key to the Iberian Polydesmus species is presented.
\end{abstract}

\section{Keywords}

Asturias, Cantabria, cave, millipede, Propolydesmus, taxonomy

\section{Introduction}

The Holarctic family Polydesmidae comprises of more than 240 occurring species, with 192 recorded in Europe (Kime and Enghoff 2011; Enghoff et al. 2015). Most species belong to the genera Polydesmus Latreille, 1802/1803 and Brachydesmus Heller,

Copyright Per Djursvoll. This is an open access article distributed under the terms of the Creative Commons Attribution License (CC BY 4.0), which permits unrestricted use, distribution, and reproduction in any medium, provided the original author and source are credited. 


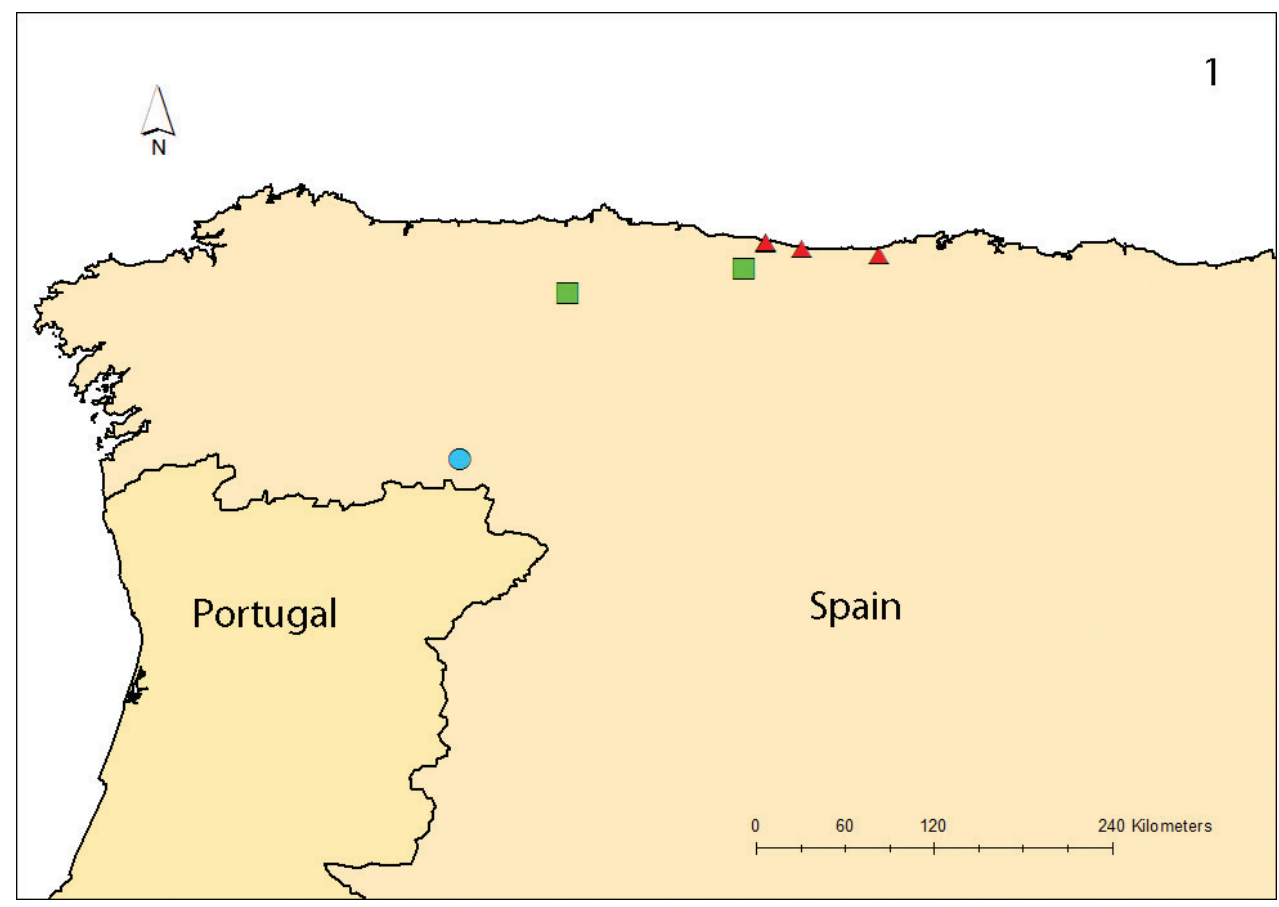

Figure I. Records of $P$. haroi (Mauriès \& Vicente, 1977), blue circle; $P$. asturiensis sp. nov., green square; P. biscayensis sp. nov., red triangle.

1858. However, new species are detected, even in Europe, particularly in the Mediterranean region and in caves (e.g., Mauriès 2013, 2014; Antić et al. 2013a, b; Gilgado et al. 2015). From the Iberian Peninsula, Azores, Madeira, Canary Islands, and Balearic Islands, 33 species in six genera, Polydesmus (10 spp.), Propolydesmus Verhoeff, 1895 (5 spp.), Archipolydesmus Attems, 1898 (9 spp.), Schizomeritius Verhoeff, 1931 (6 spp.), Brachydesmus (2 spp.) and Tolosanius Attems, 1952 (1 sp.) are recorded (see Table 1). Notably, most of them are endemic to the Iberian Peninsula.

Two new species of Polydesmus are described below, based on material housed in the Museo Nacional de Ciencias Naturales, Madrid. They were collected in northern Spain, from five localities in Asturias and one in Cantabria (Fig. 1).

Both species have strongly bifurcate gonopods, with well-developed endomere (endm) and exomere (exm) (see terminology in Djursvoll 2008). Based on the length and shape of the endomere and exomere, including the length and orientation of the seminal groove, the new species are placed in the genus Polydesmus, as diagnosed by Djursvoll et al. (2001). Some of these character states are also present in species considered by Enghoff and Golovatch (2003) to belong in the genus Propolydesmus, notably Polydesmus haroi Mauriès \& Vicente, 1977 and Polydesmus racovitzai Brolemann, 1910. After an in-depth examination and comparison of the gonopod morphology, both species are transferred back to Polydesmus in the present paper. 
Table I. Species of Polydesmidae in Portugal and Spain and its known distribution.

\begin{tabular}{|c|c|c|c|}
\hline Species & Portugal & Spain & Province/region \\
\hline $\begin{array}{l}\text { Archipolydesmus altibaeticus Gilgado, } \\
\text { Enghoff, Tinaut \& Ortuño, } 2015\end{array}$ & & $x$ & Granada \\
\hline Archipolydesmus bedeli (Brolemann, 1902) & & $x$ & Segovia, Madrid and Guadalajara \\
\hline Archipolydesmus cordubaensis Mauriès, 2013 & & $x$ & Córdoba \\
\hline $\begin{array}{l}\text { Archipolydesmus foliatus Gilgado, Enghoff, } \\
\text { Tinaut \& Ortuño, } 2015\end{array}$ & & $x$ & Alicante \\
\hline Archipolydesmus giennensis Mauriès, 2014 & & $x$ & Jaén \\
\hline Archipolydesmus osellai Ceuca, 1968 & & $x$ & Huesca \\
\hline Archipolydesmus panteli (Brolemann, 1900) & & $x$ & Cuenca, Tarragona and Lleida \\
\hline Archipolydesmus ribauti (Brolemann, 1926) & & $x$ & Gerona \\
\hline Archipolydesmus terreus (Attems, 1952) & & $x$ & Cádiz and Gipuzkoa \\
\hline Brachydesmus proximus Latzel, 1889 & $x$ & $x$ & $\begin{array}{c}\text { Madeira, Azores, Canary Islands, Balearic Islands, Huesca, } \\
\text { Malaga }\end{array}$ \\
\hline Brachydesmus superus Latzel, 1884 & $x$ & $x$ & $\begin{array}{c}\text { Azores, Madeira, Lisbon, Balearic Islands, Canary Islands, } \\
\text { Granada, Orense, Pontevedra, Zamora, Burgos, Madrid, } \\
\text { Tarragona, La Rioja, Córdoba, Segovia, Navarra, } \\
\text { Álava, Barcelona }\end{array}$ \\
\hline Polydesmus angustus Latzel, 1884 & & $x$ & Álava, Asturias \\
\hline Polydesmus asturiensis sp. nov. & & $x$ & Asturias \\
\hline Polydesmus biscayensis sp. nov. & & $x$ & Asturias, Cantabria \\
\hline Polydesmus coriaceus Porat, 1871 & $x$ & $x$ & Widely distributed in northern Iberia and adjacent islands \\
\hline Polydesmus geochromus Attems, 1952 & & $x$ & Jaén, Sevilla \\
\hline Polydesmus haroi (Mauriès \& Vicente, 1977) & & $x$ & Zamora \\
\hline Polydesmus incisus Brolemann, 1921 & & $x$ & Pyrenees, Girona, Huesca \\
\hline Polydesmus inconstans Latzel, 1884 & $\times$ & $x$ & Navarra, Huesca, Madrid, Orense, Pontevedra, Viana do Castelo \\
\hline $\begin{array}{l}\text { Polydesmus minutulus Mauriès \& } \\
\text { Barraqueta, } 1985\end{array}$ & & $x$ & Viscaya \\
\hline Poydesmus racovitzai (Brolemann, 1910) & & $x$ & Gipuzkoa, Viscaya, Navarra \\
\hline Propolydesmus dismilus (Berlese, 1891) & & $x$ & $\begin{array}{c}\text { Balearic Islands, Canary Islands, Valencia, Granada, Zamora, } \\
\text { Huesca, Salamanca, Álava, Madrid, Segovia, Cuenca, Zaragoza, } \\
\text { Toledo, Alicante, Guadalajara, Burgos }\end{array}$ \\
\hline Propolydesmus heroldi (Schubart, 1931) & & $\times$ & Sevilla \\
\hline Propolydesmus laevidentatus (Loksa, 1967) & $\times$ & $x$ & Canary Islands, Orense, Pontevedra, Minho, Azores, Madeira \\
\hline Propolydesmus miguelinus (Attems, 1908) & $x$ & & Beira Litoral, Azores, Madeira \\
\hline Propolydesmus pectiniger (Verhoeff, 1893) & $\times$ & & Beira Litoral \\
\hline Schizomeritius phantasma (Verhoeff, 1925) & & $x$ & Madrid and Àvila \\
\hline Schizomeritius andalusis Djursvoll, 2008 & & $x$ & Sevilla, Huelva and Cadis \\
\hline Schizomeritius armatus (Machado, 1946) & $x$ & & Beira Litoral \\
\hline Schizomeritius esgrimidor Djursvoll, 2008 & & $x$ & Àvila \\
\hline Schizomeritius mauriesi (Vicente, 1979) & & $x$ & Caceres \\
\hline Schizomeritius ortizi Djursvoll, 2008 & & $x$ & Toledo \\
\hline Tolosanius parvus Attems, 1952 & & $\times$ & Gipuzkoa \\
\hline
\end{tabular}

\section{Materials and methods}

Preserved specimens were examined in $70 \%$ ethanol using a Leica MZ Apo stereomicroscope. When making Scanning Electron Micrographs (SEM), structures such as gonopods and antennae were gently mounted on stubs using sticky tabs and the airdried stubs were sputter coated with gold. A Zeiss Supra 55 UP field emission scan- 
ning electron microscope used for observation and photographs. Photographs of tergal structures were made with an Olympus SC 50 camera mounted on an Olympus SZX 10 stereomicroscope using Olympus software.

Morphological terminology for this studied group follows Djursvoll (2008). Nonetheless, some names of the gonopod structures are specified here. Endomere, the main gonopod part which brings the seminal groove to the solenophore - surrounded with the pulvillus. The same part is identical to "solenomere" and "femorite", occasionally used by other authors. Acropodite, a tooth that originates from the distal part of endomere, always distal to the solenophore/pulvillus. The same part is identical to "distofemoral process" occasionally used by other authors. Several acropodites may occur. Exomere, gonopod part that originates basally on endomere, usually lateral and sometimes with a marked sulcus, usually with outgrowth of several teeth (processes). Abbreviations: exm $=$ exomere, $\mathrm{endm}=$ endomere, $\mathrm{t}=$ tooth $\mathrm{on}$ exomere, $\mathrm{a}=$ acropodite.

The type material is stored in the Museo Nacional de Ciencias Naturales, Madrid (MNCN). New material of Polydesmus racovitzai Brolemann, 1910 was mainly collected during a field trip in April 2009; participants were Karin Voigtländer, Hans Reip, Norman Lindner, Helen Read, Desmond Kime, Paul Richards, Steve Gregory, and Per Djursvoll. The new material of Polydesmus racovitzai is stored in the University Museum of Bergen (ZMBN) and Senckenberg Museum of Natural History Görlitz (SMNG).

\section{Taxonomy}

\section{Polydesmus biscayensis sp. nov.} http://zoobank.org/82FA05D9-FF77-4FC8-88E5-21FDF3F37A7D

Figs $2-8$

Type specimens. Spain, Asturias province; holotype $\widehat{\partial}$; Llanes, Cueva de la Colluvina; 1 Nov. 1969; E. Ortiz leg.; MNCN 20.07/1440 • paratype ${ }^{\dagger}$; same data as holotype; MNCN 20.07/2020 • paratypes $2 \hat{\jmath} \widehat{\partial}, 2$ 우 (fragments); Llanes, Bricia, La Cueva de Tebellin; C. Cardin leg.; date unknown; MNCN 20.07/1446 • paratype $\widehat{O}$ (fragments in three parts); Llanes, Piedra Llanes; 26 Jan. 1929; C. Cardin leg.; MNCN 20.07/1297. Cantabria province • paratypes $\hat{\partial}, q, 2$ juveniles (fragments); Cueva de la Busta; 7 Aug. 1968; E. Ortiz leg.; MNCN 20.07/1320.

Etymology. Named after the Bay of Biscay.

Diagnostic characters. Differs from other Polydesmus species in having a well-developed twisted endomere together with the acropodites - al close to the solenophore and a hooked acropodite $\mathrm{a} 2$ at the distalmost end, a long, slender and curly exomere, together with the presence of a ventrolateral tooth $\mathrm{t} 1$ directed proximal just after main curvature point, and the placement of the distal $\mathrm{t} 2$ tooth distally.

Description. With 20 body rings, total length $10-12 \mathrm{~mm}$. Coloration whitish to pale yellow (longtime ethanol-preserved specimens only). Collum ovoid, 


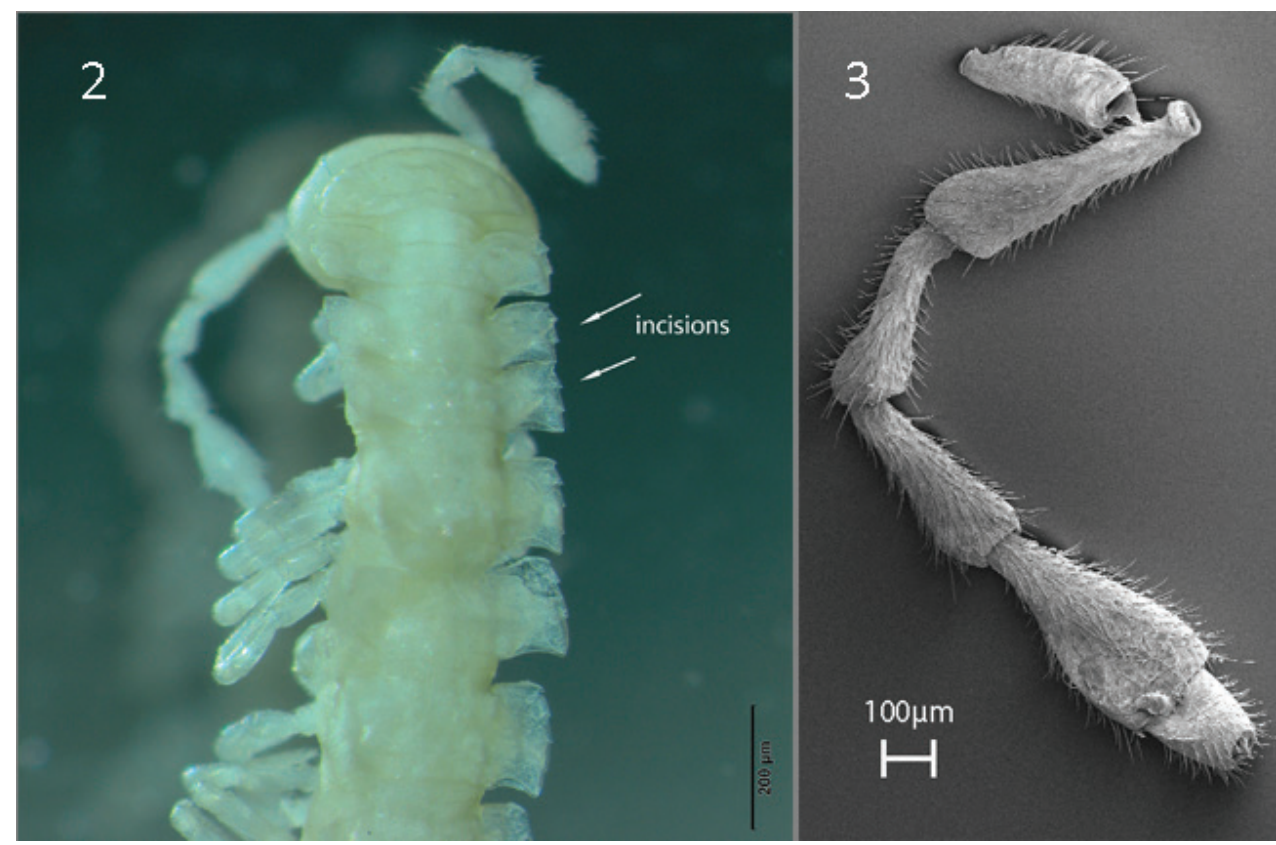

Figures 2-3. P. biscayensis sp. nov., male paratype $\mathbf{2}$ dorsal view of head and anterior body rings (MNCN 20.07/2020) 3 antenna (MNCN 20.07/1297).

narrower than head and the subsequent rectangular metatergum 2 which is approximately as wide as head, head $>$ collum $>$ metatergum 2 (Fig. 2). Antennae comparatively long, not surpassing body ring 3, antennomere 6 almost clavate and slightly longer than 4 and $5,4=5<6>>7$, with dorsoparabasal sensory knob on antennomere 7 , sensillar area on antennomere 5-7 (Fig. 3). Metaterga rectangular, paraterga projected laterad, tergal sculpture (tuberculation) in three transverse rows, third row barely visible in metaterga $2-4$. Setae clavi- to bacilliform, caudolateral part of paraterga with distinct keels especially from metarterga 4 and back. Ozopore located slightly inside caudolateral margin. Three distinct lateromarginal incisions in paratergum 2-4, four incisions on 5, incisions less distinct more posteriorly. Epiproct pointed apically. Male legs distinctly swollen, sphaerotrichomes present. Legs 1.5-2.0 times as long as midbody height, with single dorsal macrosetae on tibia.

Gonopod strongly bifurcate, including endomere and exomere, both parts twisted (curved). Endomere turns mesally crossing beneath oppositely directed exomere (Figs 4-7). Endomere stouter, bringing descending seminal groove to a mesad-directed solenophore-pulvillus surrounded with two small acropodites, al beside pulvillus, a2 hooked, and an excavation in between them (Fig. 4). Exomere originates from endomere with marked sulcus, very elongated and curly, descending to acute apex, with ventrolateral tooth $\mathrm{t} 1$ just after main curvature point directed backwards, t2 distally (Fig. 6). Prefemoral part densely setose. Lateral edge of coxite with two large macrosetae. Cannula tube-like and curved. 

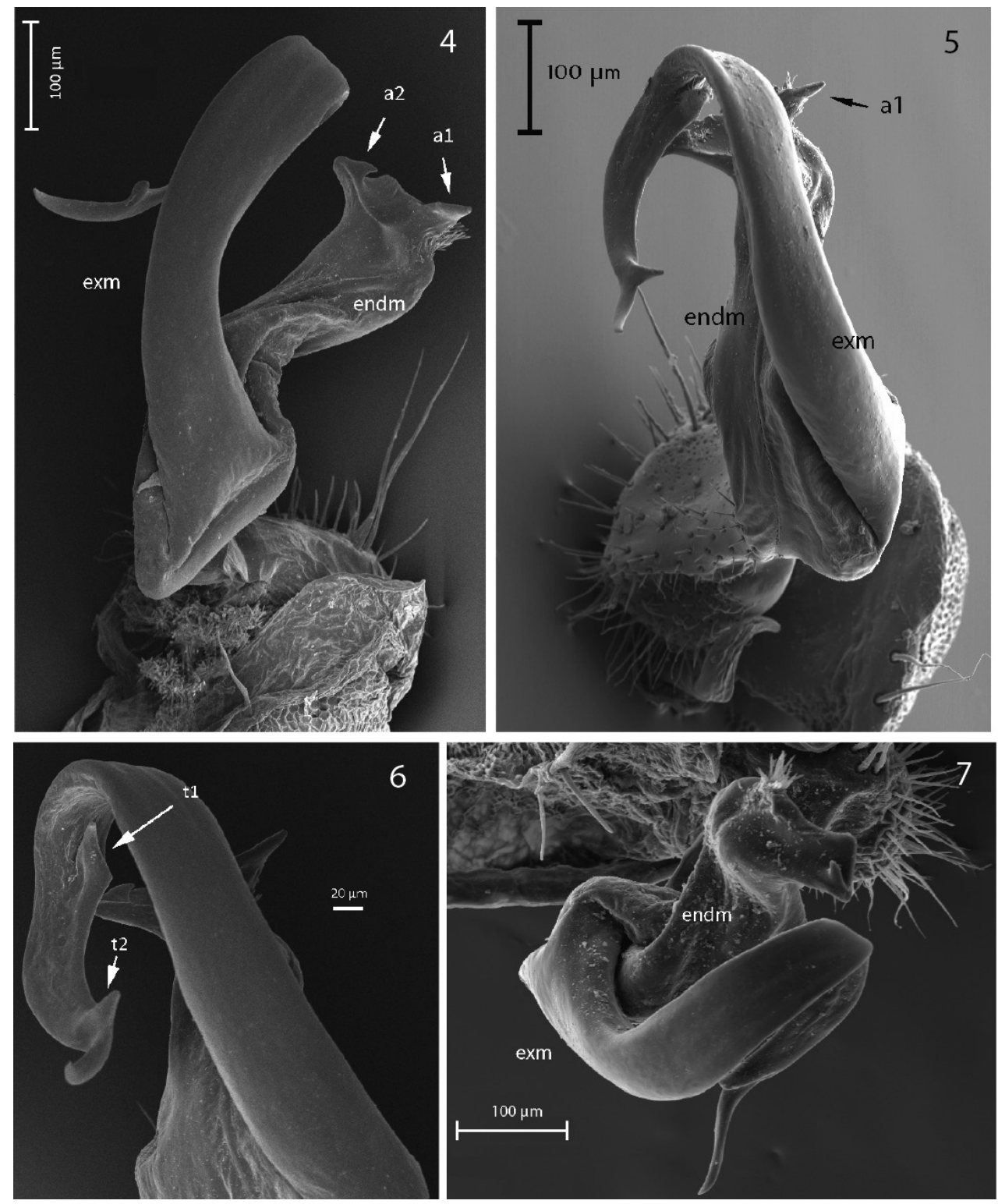

Figures 4-7. P. biscayensis sp. nov. 4 male paratype, right gonopod, dorsolateral view (MNCN 20.07/1297) 5 male holotype, right gonopod, dorsomesal view (MNCN 20.07/1440) 6 male paratype, right gonopod with ventrolateral tooth $\mathrm{t} 1$ on exomere (MNCN 20.07/1297) 7 male holotype, right gonopod, distal view (MNCN 20.07/1440).

Female with marked apophysis (tubercle) supporting the orifice of the gonopore on second coxae. Epigynal ridge poorly modified but with pin-shaped median process, with crevice inside (Fig. 8). Vulva relatively short, e.g., in lateral view less than $2 \times$ as long as high. 


\section{Polydesmus asturiensis sp. nov.}

http://zoobank.org/91CCD20A-D879-4A5E-85FC-76550041F258

Figs 9-16

Type specimens. Spain, Asturias province; holotype $\widehat{\partial}$ (fragments); Teverga, Cueva de Huerta, 750 m a.s.l.; UTM 29TQH37; July. 1934; Bolivar col.; MNCN 20.07/1484 - paratype ${ }^{\lambda}$; same data as holotype; MNCN 20.07/2021 • paratypes $\hat{\jmath}, 2$ $2+q$ (fragments); same data as holotype; MNCN 20.07/1481 • paratypes ô, 우 (fragments); Vega de Enol; ca. 1050 m a.s.l.; 2 Nov. 1969; E. Ortiz leg.; MNCN 20.07/1450.

Additional material. Two specimens in fragments, same locality data as holotype (MNCN 20.07/1484).

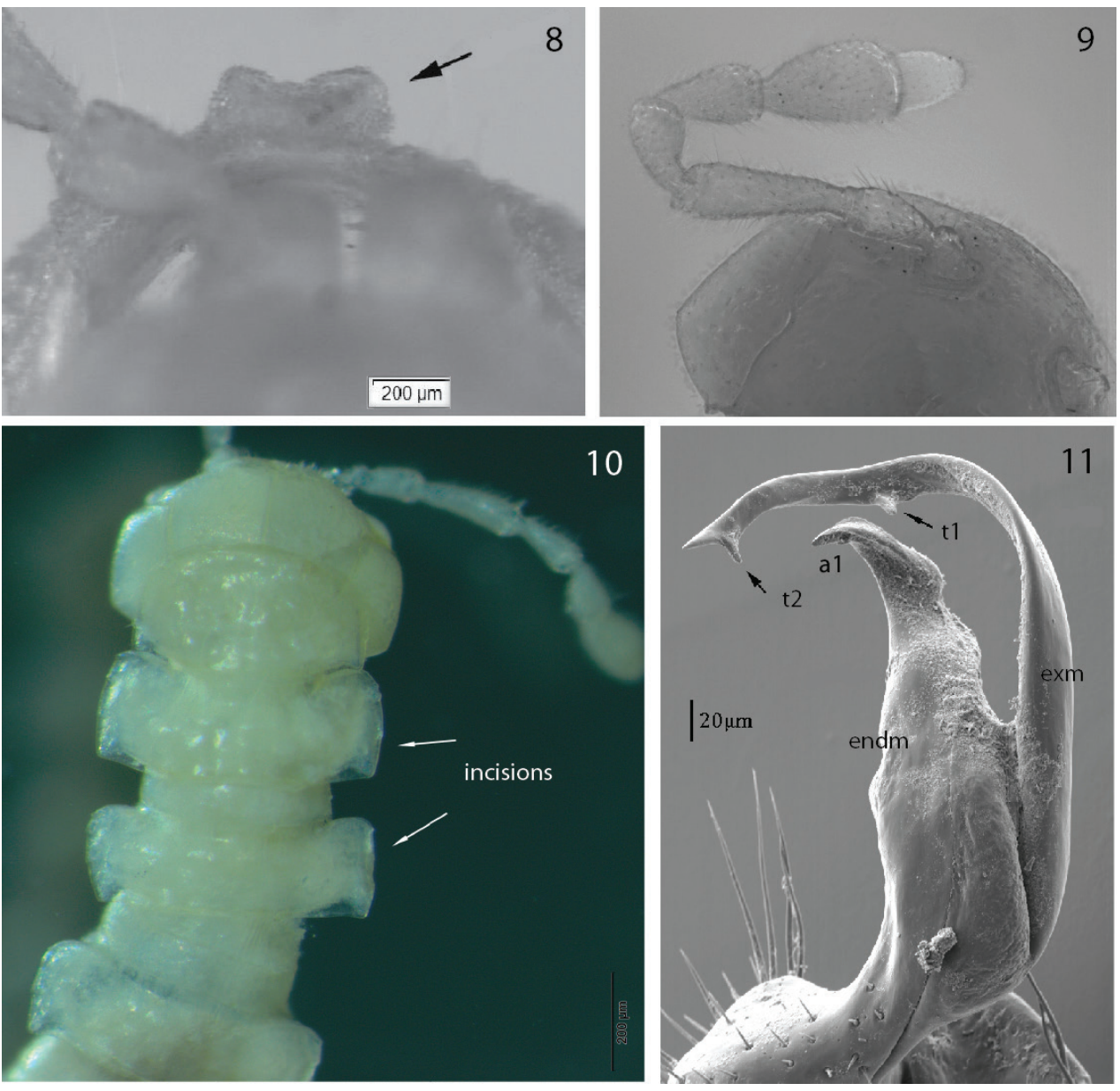

Figures 8-I I. 8 P. biscayensis sp. nov., paratype, female epigyne (MNCN 20.07/1320) 9 P. asturiensis sp. nov., paratype, antenna (MNCN 20.07/1450) IO P. asturiensis sp. nov., paratype, head and anterior body rings, dorsal view (MNCN 20.07/1481) II P. asturiensis sp. nov., male paratype right gonopod, mesal view (MNCN 20.07/1450). 

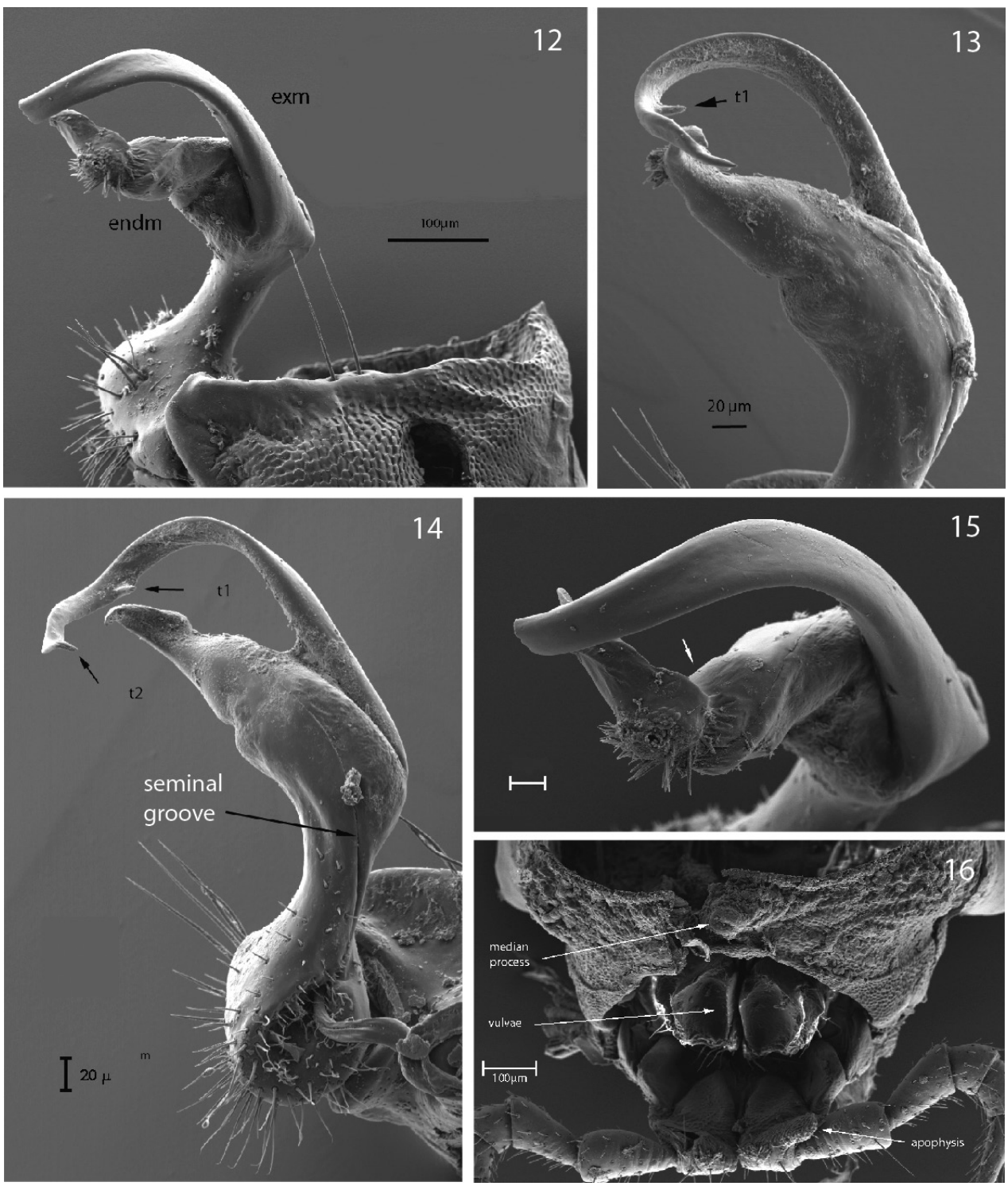

Figures I 2-16. I 2 P. asturiensis sp. nov., male paratype, left gonopod, lateral view (MNCN 20.07/1481) I3-I4 P. asturiensis sp. nov., male paratype, right gonopod, mesal view (MNCN 20.07/1450) I5 P. asturiensis sp. nov., male paratype, left gonopod, anterior view (MNCN 20.07/1481) I 6 P. asturiensis sp. nov., paratype, female epigyne and vulva (MNCN 20.07/1481).

Etymology. Named after the province of Asturias.

Diagnostic characters. Differs from other Polydesmus species in having a twisted endomere with a distinct cleavage basad to the solenophore-pulvillus, with acute a1 distally. Exomere subfalcate, long and slender, with a ventrolateral right-angled tooth t1 just after main curvature point and together with the placement of the distal second tooth $\mathrm{t} 2$ close to apex. 
Description. With 20 body rings, total length $7-10 \mathrm{~mm}$. Coloration whitish to pale yellow (long-term ethanol-preserved specimens only). Tegument shiny. Collum ovoid, much narrower than head and metaterga 2, head $>>$ collum $<<$ metatergum 2 (Fig. 10). Antennae comparatively long, not surpassing somite 3, antennomere 6 almost clavate, slightly longer than 4 and 5, $4=5<6>>7$. With dorsoparabasal sensory knob on antennomere 7, sensillar area on antennomere 5-7 (Fig. 9). Metaterga almost rectangular, tergal sculpture (tuberculation) in three transverse rows, third row barely visible in metaterga 2-4. Paraterga horizontal and rounded anterolaterally, paraterga 2-8 with barely visible lateromarginal incisions (not serrate), with gradually larger caudolateral projections from paraterga 5. Setae minute, barely visible. Ozopore located slightly inside caudolateral margin. Epiproct pointed apically. Male legs distinctly swollen, sphaerotrichomes present. Legs 1.5-2 times as long as midbody height, with single dorsal macrosetae on tibia.

Gonopod strongly bifurcate, including endomere and exomere (Figs 11-15). Endomere stouter, somewhat twisted, with descending seminal groove crossing beneath exomere to a distad-projecting solenophore-pulvillus, cleavage almost cut it into pieces behind solenophore-pulvillus, al distally smooth and pointed (Fig. 15). Exomere curved, originating from endomere with sulcus, with $\mathrm{t} 1$ and $\mathrm{t} 2$ tooth. Prefemoral part densely setose. Lateral gonocoxal edge with two large macrosetae.

Female with marked apophysis (tubercle) supporting the orifice of the gonopore on second coxae (Fig. 16). Epigynal ridge poorly modified but with pin-shaped median process, with crevice inside. Vulva relatively short, e.g., from lateral view less than $2 \times$ as long as high.

\section{Polydesmus haroi Mauriès \& Vicente, 1977}

Fig. 20

Polydesmus haroi Mauriès \& Vicente, 1977: 530.

Polydesmus (Hormobrachium) haroi Vicente, 1979: 23.

Propolydesmus haroi (Mauriès \& Vicente, 1977): Enghoff and Golovatch (2003: 82), Kime and Enghoff (2011: 69), Djursvoll and Melic (2015: 8).

Notes. The species was figured and described in detail by Mauriès and Vicente (1977) based on material collected at Lago de Sanabria in Zamora province, with the main characters being the gonopod with two main gonopodal branches, exomere and endomere, and the seminal groove and solenophore-pulvillus extended onto endomere. These two characters differ from Propolydesmus but are in accordance with and support a phylogenetic relationship with the genus Polydesmus Latreille, 1802/03, and its type species Polydesmus complanatus Linnaeus, 1761.

It has similarities with $P$. asturiensis sp. nov. and P. biscayensis sp. nov. but differ in having a shorter exomere, the solenophore-pulvillus placed dorsally on the endomere and directed towards the exomere (Fig. 20), a wider space between the endomere and exomere, and in having a larger body size (length $17 \mathrm{~mm}$ ). Propolydesmus haroi is here transferred back to Polydesmus. 


\section{Polydesmus racovitzai Brolemann, 1910}

Fig. 19

Polydesmus racovitzai Brolemann, 1910: 352: Attems 1927: 55, Demange 1981: 125, figs 170, 171.

Polydesmus (Hormobrachium) racovitzai Brolemann, 1910: Attems 1940: 48.

Propolydesmus racovitzai (Brolemann, 1910): Enghoff and Golovatch 2003: 82, Kime and Enghoff 2011: 69, Djursvoll and Melic 2015: 8.

Material examined. SPAIN - Viscaya province $\bullet 1 \delta^{\lambda} ; 4 \mathrm{~km} s$ of Arrazua; pinewood; Desmond Kime leg.; 4.4.1978; ZMBN-ENT-PDESMID-49. - Gipuzkoa province - 1 गे; Sierra de Aralar, Tolosa, $500 \mathrm{~m}$ south of Bedaio/Goikoa; 43.0494N, 2.04W; ca. 420 m a.s.l.; 21.4.2009; Helen Read leg.; farm buildings, under stones and logs; ZMBN-ENT-PDESMID-66・2 $\widehat{\partial} \widehat{\partial}$; same collecting data as for preceding; 22.4.2009; Desmond Kime leg.; ZMBN-ENT-PDESMID-146, ZMBN-ENT-PDESMID-194)• 1 J; Sierra de Aralar, Beasain, road from Lazkao to Etxarri-Aranaz, west of the Pass Puerto de Lizzarusti; 42.9572N, 2.1122W; ca. 550 m a.s.l.; 21.4.2009; Voigtlander, Reip \& Lindtner leg.; forest of Fagus, in leaf litter; SMNG-14763. - Navarra province - 2 ○े, 2 juveniles; Leitza, Ariz Mendiak, between area "Ustarleku" and "Karobieta" above side stream to Gorriztaran; 43.0778N, 1.8775W; ca. 615 m a.s.l.; 20.04.2009; Per Djursvoll leg.; grove of Castanea, pollard trees on the slope with Ranunculus ficaria, Daphne, Helleborus, Salvia, Rubus, Lathrea, loamy and calcareous soil, under leaves and dead wood; ZMBN-ENT-PDESMID-133, ZMBN-ENT-PDESMID-135・ 1 ○; Leitza, town area; 43.0788N, 1.9161W; ca. 470 m a.s.l.; 20.4.2009; Steve J. Gregory leg.; garden around casa rurale Aztieta; ZMBN-ENT-PDESMID-185 • 1 $\widehat{\partial}$, + ; Lekunberri, local exit N-130 direction to Betelu, 43.011N, 1.902W; ca. 580 m a.s.l.; 20.4.2009; Per Djursvoll leg.; industrial area, synantropic, meadow with stones and brick waste, under stones; ZMBN-ENT-PDESMID-145 • 4 §ô, 1 juvenile; Sierra de Aralar, south Baraibar, on road NA-7510 to Santuario de San Miguel; 42.9762N, 1.9318W; ca. 670 m a.s.l.; 22.4.2009; Per Djursvoll leg; under stones, in Corylus litter; ZMBN-ENT-PDESMID-142 1 क , Sierra de Urbasa, Alava, under northern border, on road A-2128 south of Opakua, 42.821N, 2.3549W; ca. $740 \mathrm{~m}$ a.s.l.; 23.4.2009; Steve J. Gregory leg.; woodland of Corylus, Quercus and Crategus; ZMBN-ENTPDESMID-181 - 1 \%; Sierra de Urbasa, on top at southern cliff border, east of road NA-7182, 42.7989N, 2.1417W; ca. 930 m a.s.l.; 23.4.2009; Steve J. Gregory leg.; pasture on stony ground, some thorny bushes, occasional trees or groups of Fagus;

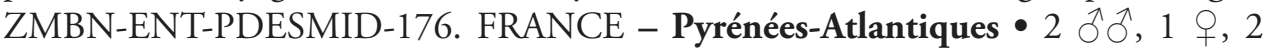
juveniles; Tarnos; 43.5203N, 1.4639E, ca. 30 m a.s.l.; 26.4.2009; Desmond Kime \& Per Djursvoll leg. mixed deciduous forest; ZMBN-ENT-PDESMID-143.

Notes. The species was described by Brolemann (1910) and is distributed in the French Pyrenees, and in northern Spain. Body length is $13-16 \mathrm{~mm}$, the gonopods may resemble those of Polydesmus inconstans Latzel, 1884 (see Demange 1981: 125, figs 170 - 171). It differs from $P$. inconstans in having a row of teeth dorsally on the endomere 

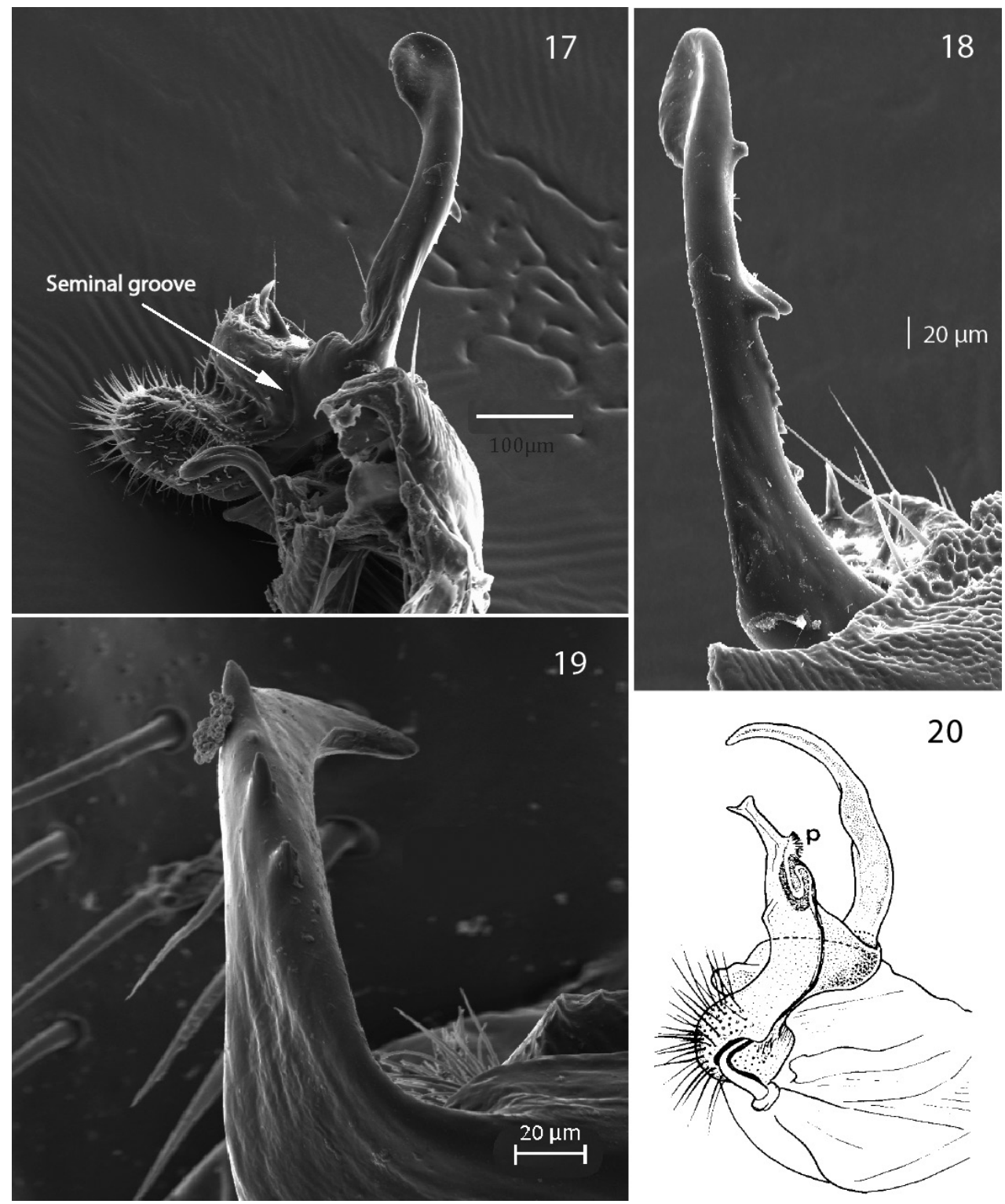

Figures 17-20. 17 Propolydesmus laevidentatus (Loksa, 1967), from Madeira, right gonopod, medial view (ZMBN-ENT-PDESMID-342) I8 Propolydesmus laevidentatus (Loksa, 1967), from Madeira, right gonopod, lateral view (ZMBN-ENT-PDESMID-342) 19 P. racovitzai (Brolemann, 1910) right gonopod, lateral view (MNCN 20.07/1435) 20 P. haroi (Mauriès \& Vicente, 1977) gonopod, redrawn after Mauriès and Vicente (1977).

and if this character was not observed, probably misidentified as P. inconstans (Fig. 19) in the literature. It differs from species of the genus Propolydesmus with the presence of the well-developed exomere and endomere - with seminal groove and solenophore- 

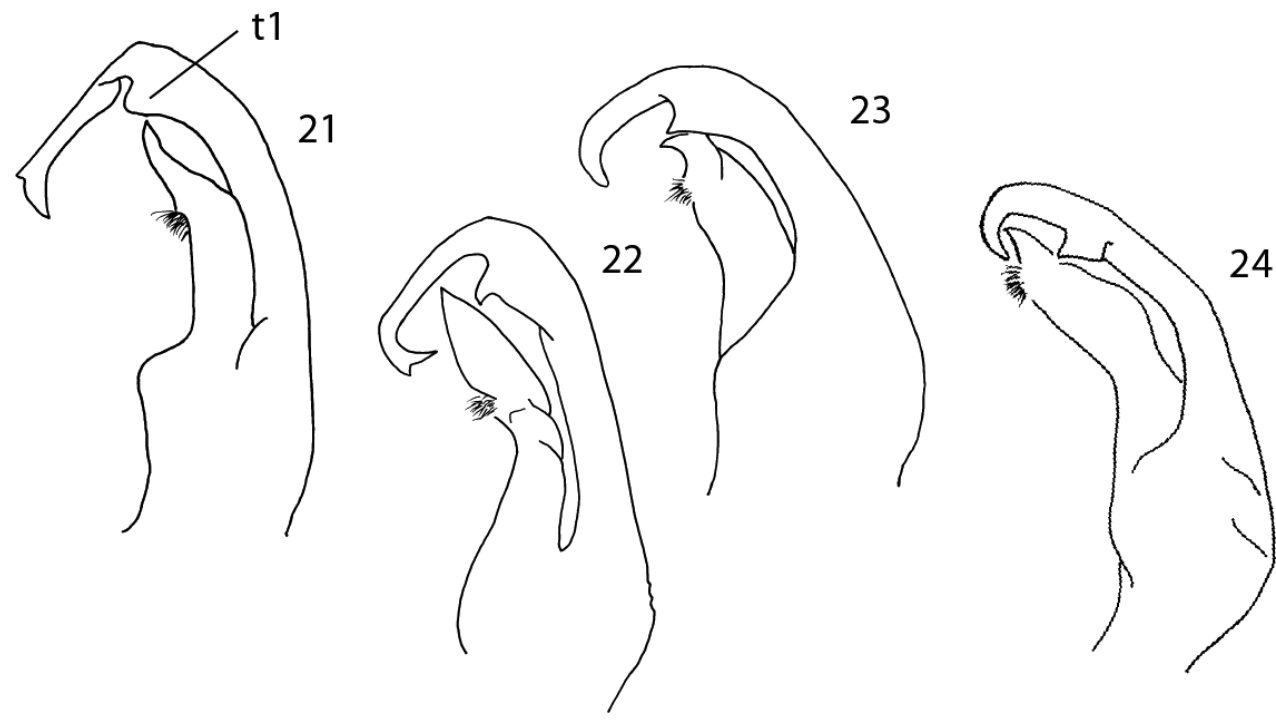

Figures 2I-24. 2 I Sketch of the gonopod of $P$. angustus Latzel, 188422 Sketch of the gonopod of $P$. incisus Brolemann, 192123 Sketch of the gonopod of P. inconstans Latzel, 188424 Sketch of the gonopod of $P$. coriaceus Porat, 1871.

pulvillus extended onto. These characters conform to those of the genus Polydesmus Latreille, 1802/03, and with its type species Polydesmus complanatus Linnaeus, 1761. Propolydesmus racovitzai is here transferred back to Polydesmus.

\section{Key to the Iberian species of Polydesmus}

1 With 19 body rings in both sexes ......P. minutulus Mauriès \& Barraqueta, 1985

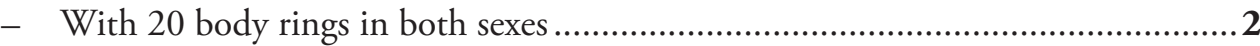

2 Gonopod unipartite, as in Brachydesmus Heller, 1858

P. geochromus Attems, 1952

- Gonopod bifurcate - exomere and endomere distinct ........................................ 3

3 Exomere with a lateral tooth ( $\mathrm{t} 1$ ) at main curvature point (Figs 21-24) ..............4

- Exomere with a ventrolateral tooth (t1) at main curvature point (Figs 6, 11, 1314)

4 T1-tooth at main curvature point on exomere quadrangular or blade-like (Fig. 24) P. coriaceus Porat, 1871

- T1-tooth at main curvature point on exomere almost absent or triangular (Figs 21-23)

5 Endomere and exomere branches widely separated.

P. haroi Mauriès \& Vicente, 1977

- Endomere and exomere branches not widely separated

6 Endomere apically stout and blunt, somewhat hooked (Figs 23-24) ...................

- Endomere apically pointed - a1, not hooked (Figs 21-22) ..................................8 
7 With row of teeth dorsally on exomere (Fig. 19) ..... P. racovitzai Brolemann, 1910

- Without row of teeth dorsally on exomere ................. P. inconstans Latzel, 1884

8 Acropodite narrow and acute (Fig. 21) .......................... P. angustus Latzel, 1884

- Acropodite broad, leaf-shaped, with acute apex (Fig. 22) ... P. incisus Brolemann, 1921

9 Endomere with distinct cleavage, without acropodite a2 (Fig. 15)

P. asturiensis sp. nov.

- Endomere without distinct cleavage, with acropodites a1 and a2 (Fig. 4)

P. biscayensis sp. nov.

\section{Discussion}

Enghoff and Golovatch (2003) redefined the small and solely southwestern European genus Propolydesmus Verhoeff, 1895, adding 12 species formerly placed in Polydesmus and adding one previously recognized Propolydesmus in synonymy, thus increasing the number of included species from four to 15. Consequently, the range of Propolydesmus has greatly expanded eastwards in Europe. Many of the species had been placed in subgenus Hormobrachium (Attems, 1940), that was synonymized with Polydesmus (s. str.) by Djursvoll et al. (2001). Later Djursvoll (2008) transferred Propolydesmus mauriesi (Vicente, 1979) to Schizomeritius Verhoeff, 1931. Without a species-level revision and a comprehensive analysis, the attributions of some of the species to Propolydesmus by Enghoff and Golovatch (2003) may be premature, as several of the species seem to have their affinities elsewhere.

Both Verhoeff (1895) and Djursvoll et al. (2001) in Propolydesmus diagnoses emphasized the character with particularly reduced endomere, while Enghoff and Golovatch (2003) stated "a relatively to very short/stout gonopod femorite". This may have opened for the more extensive interpretation. However, Enghoff and Golovatch added for Propolydesmus, the important gonopodal character - presence of a seminal cavity, found in Propolydesmus laevidentatus (Loksa, 1967), in contrast to Verhoeff (1895) and Djursvoll et. al. (2001). In particular, Propolydesmus laevidentatus, as illustrated by Enghoff and Golovatch (2003: 83, figs 4-7) differs from Polydesmus by having a strongly reduced endomere, and a slightly curved exomere with numerous teeth (Figs 18, 19). In addition, a looped seminal groove that does not extend onto the endomere branch, also in accordance with the type species Propolydesmus pectiniger (Verhoeff, 1893).

\section{Acknowledgments}

I am indebted to Dra. Begoña Sánchez Chillón, curator of arthropod collection at the Museo Nacional de Ciensias Naturales, Madrid, for the loan of the polydesmid material, to Egil Severin Erichsen at the ELMIR lab (UiB) for assistance with operating the scanning electron microscope. Thanks are due to Gunnar Kvifte and Trond Andersen (UiB) for comments on previous drafts. Special thanks to the reviewers Nesrine Akkari and Henrik Enghoff for constructive suggestions and useful comments. 


\section{References}

Antić DŽ, Ćurčić BPM, Mitic BM, Tomić VT, Lučić LR, Dudić BD, Stojanović DZ, Makarov SE (2013a) A new cave diplopod of the genus Brachydesmus Heller, 1858 from Southwest Serbia (Diplopoda: Polydesmida: Polydesmidae). Archives of Biological Sciences, Belgrade 65(2): 745-750. https://doi.org/10.2298/ABS1302745A

Antić, DŽ, Curčić BPM, Tomić VT, Rada T, Rada B, Milinčić MA, Makarov SE (2013b) Two new species of Brachydesmus Heller, 1858 from the Balkan peninsula (Diplopoda: Polydesmida: Polydesmidae). Archives of Biological Sciences, Belgrade 65(3): 1233-1243. https:// doi.org/10.2298/ABS1303233A

Attems CG (1927) Über palaearktische Diplopoden. Archiv für Naturgeschichte 92(1-2): $1-256$.

Attems CG (1940) Myriapoda 3. Polydesmoidea III. Fam. Polydesmidae, Vanhoeffeniidae, Cryptodesmidae, Oniscodesmidae, Sphaerotrichopidae, Periodontodesmidae, Rhachidesmidae, Macellolophidae, Pandirodesmidae. Das Tierreich 70: 1-577. https://doi. org/10.1515/9783111609645

Demange J-M (1981) Les Mille-Pattes, Myriapodes, Généralités, Morphologie, Écologie - Détermination des espèces de France. Société Nouvelle des Éditions Boubée, Paris, 284 pp.

Djursvoll P (2008) Revision of the Iberian millipede genus Schizomeritus Verhoeff, 1931 (Diplopoda: Polydesmidae), with the description of three new species. International Journal of Myriapodology 1(1): 111-122. https://doi.org/10.1163/187525408X316776

Djursvoll P, Melic A (2015) Orden Polydesmida. Revista IDE@, SEA 28: 1-11.

Djursvoll P, Golovatch SI, Johanson KA, Meidell B (2001) Phylogenetic relationships within Polydesmus sensu lato (Diplopoda: Polydesmidae). Fragmenta Faunistica 43: 37-57.

Enghoff H, Golovatch SI (2003) The millipede genus Propolydesmus Verhoeff, 1895 redefined, with a revision of the genus in the Canary Islands (Diplopoda, Polydesmida, Polydesmidae). Graellsia 59(1): 79-86. https://doi.org/10.3989/graellsia

Enghoff H, Golovatch S, Short M, Stoev P, Wesener T (2015) Diplopoda - Taxonomic overview. In: Minelli A (Ed.) Treatise on Zoology - Anatomy, Taxonomy, Biology. The Myriapoda, Vol. 2. Brill, Leiden, 363-447. https://doi.org/10.1163/9789004188273_017

Gilgado JD, Enghoff H, Tinaut A, Ortuno VM (2015) Hidden biodiversity in the Iberian Mesovoid Shallow Substratum (MSS): New and poorly known species of the millipede genus Archipolydesmus Attems, 1898 (Diplopoda, Polydesmidae). Zoologischer Anzeiger 258: 13-38. https://doi.org/10.1016/j.jcz.2015.06.001

Kime RD, Enghoff H (2011) Atlas of European Millipedes (Class Diplopoda). Volume 1, Orders Polyxenida, Glomerida, Platydesmida, Siphonocryptida, Polyzoniida, Callipodida, Polydesmida. Co-published by Pensoft Publishers Sofia-Moscow and European Invertebrate Survey, Leiden, $282 \mathrm{pp}$.

Mauriès JP (2013) Three new species of cavernicolous millipedes from Andalusia, Spain (Diplopoda: Polydesmida: Polydesmidae; Chordeumatida: Vandeleumatidae, Opisthocheiridae). Trois espèces nouvelles de diplopodes cavernicoles de l'Andalousie (Espagne) (Diplopoda: Polydesmida: Polydesmidae; Chordeumatida: Vandeleumatidae, Opisthocheiridae). Arthropoda Selecta 22(2): 97-112. https://doi.org/10.15298/arthsel.22.2.01 
Mauriès JP (2014) Four new species of cavernicolous millipedes from Andalusia, Spain (Diplopoda: Polydesmida: Polydesmidae; Chordeumatida: Chamaesomatidae, Opisthocheiridae). Quatre espèces nouvelles de Diplopodes cavernicoles de l'Andalousie (Espagne) (Diplopoda: Polydesmida: Polydesmidae; Chordeumatida: Chamaesomatidae, Opisthocheiridae). Arthropoda Selecta 23(1): 33-50. https://doi.org/10.15298/arthsel.23.1.03

Mauriès JP, Vicente MC (1977) Myriapodes Diplopodes nouveaux ou peu connus des Pyrénées espagnoles, des monts Cantabriques et de Galice. Bulletin du Muséum national d'Histoire naturelle, $3^{\text {e }}$ série, Zoologie 315(452): 529-546.

Verhoeff KW (1895) Aphorismen zur Biologie, Morphologie, Gattungs- und Art-Systematik der Diplopoden. Zoologischer Anzeiger 18: 203-211, 213-226, 237-244.

Vicente MC (1979) Diplopodos polidesmidos de Zamora, Salamanca y Cáceres (España). Descripción de una nueva especie del género Polydesmus Latreille, 1802-3 (Diplopoda, Polydesmidae). Miscelánea zoológica 5: 21-23. 